\title{
三次元再構成を行わない視覚サーボ系のための 障害物回避軌道の生成
}

\author{
細 田耕*1 阪 本 健 二*2 浅 田 稔*1 \\ Trajectory Generation for Obstacle Avoidance of \\ Uncalibrated Stereo Visual Servoing without 3D Reconstruction
}

\author{
Koh Hosoda $^{* 1}$, Kenji Sakamoto*2 and Minoru Asada ${ }^{* 1}$
}

\begin{abstract}
In this paper, a trajectory generator for a visual servoing system with two cameras is proposed to make the system accomplish obstacle avoidance tasks in unknown environments. Using the estimated epipolar constraint between two cameras, the proposed scheme can generate trajectories for the visual servoing system on the $2 \mathrm{D}$ image planes by a simple obstacle avoidance method without reconstructing 3D geometry. The proposed scheme is based on the idea, "as long as one of projected trajectories does not intersect with projected obstacles, the trajectory in $3 \mathrm{D}$ space can avoid the obstacles." An experimental result is shown to demonstrate the validity of a combination of the proposed trajectory generator and the visual servoing control scheme.
\end{abstract}

Key Words: Visual Servoing, Epipolar Constraint, No 3D Reconstruction, Obstacle Avoidance

1.はじめに

未知あるいは動的に変化する環境内でロボットが与えられた タスクを実行するときに，環境の状態を観測したり，そのタス クの成否を観測したりするために視覚センサの果たす役割は大 きい，視覚センサから得られた情報をもとにロボットを制御す るにあたって，様々なロボットに種々の作業をさせるためには， 得られた視覚情報を三次元再構成し，より抽象的なデータとす るのが都合が良い。従来の視覚に関する研究はこのような観点 に基づき, 視覚情報処理をロボットの制御と独立に扱い，その 精度を上げることに専念してきた。しかしながら実際には，口 ボット自身の行動と必要な視覚情報処理の間には密接な関係が あり $[1]$ ，キャリブレーションやセンサ配置問題など，おのおの 単独では装置や時間のコストがかかってしまう問題を，この関 係を利用することにより簡単に解くことができることが分かつ てきた。

一方, 視覚を持つロボットに作業をさせる場合の制御則とし て, 視覚情報を直接ロボットの制御ループに組み込む視覚サー ボ系が注目を集めている[2][3]. 視覚サーボ系を用いることに より, キャリブレーション誤差や外乱に強いロボットシステム を構成することができる，視覚サーボ系の研究において，前述 のようにセンサから得られる情報から環境の三次元情報を再構

原稿受付 1996 年 2 月 8 日

${ }^{* 1}$ 大阪大学工学部

$* 2$ 大阪大学工学部, 現在松下電工株式会社に勤務

${ }^{* 1}$ Osaka University

${ }^{* 2}$ Osaka University, currently with Matsushita Electric Works, Ltd.
成し，これをサーボ系に利用する方法（文献 [4] など）も提案 されているが, 特に制御ループに直接視覚情報をフィードバッ クしてサーボ系の応答速度を上げることが目的の一つであるの で，このような再構成を極力排除するのが望ましいと考えら れる。しかしながら, 画像平面上のセンサ情報を直接フィード バックする視覚サーボ系においては，環境の三次元再構成をし ないために，センサによりとらえられる画像特幑量を目標値に 収束させるという単純なサーボ系の動作によって与えられた作 業を遂行しなければならない。そのため, 画像特徴量の目標值 を与えられた作業に応じてどのように生成するかが大きな問題 となる. 従来の研究 [5]〜 [8] では, 目標画像特徵量は固定で視 覚サーボ系自体の性能を議論するものがほとんどで, 目標画像 特徴量軌道を計画することにより作業を遂行する方法の提案が 重要であるのにもかかわらず, これについて論じているものは ほとんどなかった．筆者らの知る限り，Hager [9][10]が線分 で記述されるような環境下で，ステレオカメラ間に存在するエ ピポーラ拘束を利用して, フロッピーディスクを差す軌道を生 成し，動作を視覚サーボ系で実現する手法を示しているのみで ある。

本報告では，視覚を持つロボットの作業として，マニピュレー 夕の障害物回避を想定し, 視覚情報から障害物の三次元再構成 をせずに，障害物回避作業を遂行するための軌道生成につい て述べる、ロボットが, 視覚として相対的位置姿勢の固定され た 2 台のカメラを持つものとすると, そのカメラの画像間には 幾何学的拘束 (エピポーラ拘束) が存在することが知られてい る [11].この拘束を利用し,「2台のカメラの画像上で, 障害物 
の像に同時に干涉していない軌道は, 実際の空間においても障 害物と干涉していない」という十分条件に基づくと, 三次元空 間内の障害物回避問題は，二次元平面内の問題に㷌着されるこ とが分かる.この問題に対し，適当な二次元の障害物回避アル ゴリズムを用いることにより障害物回避軌道を生成できること を示す，提案する方法は，障害物が画像上で背景から抽出され ているような環境下であれば，カメラ間での対応がついていな くても適用可能であり, より適用範囲が広いと考えられる. 最 後に提案する手法を用いて生成した軌道をロボットシステムに 適用することにより，その有効性を検証する。

\section{2. 三次元障害物回避問題の二次元問題への帰着}

\section{1 障害物回避作業}

本論文で視覚を持ったロボットに与えられる作業は, 手先の 始点位置, 終点位置が与えられたときに, 障害物を回避しなが ら始点から終点に移動することである（Fig.1）。ここではロ ボットは 2 台のカメラを持つと想定しているが，以下の議論は 3 台以上のカメラを持つ場合にも適用可能である.

画像処理, カメラおよび与えられる作業について以下の仮定 をおく.

（1）画像上の障害物の領域は, 適当な画像処理方法により背景 から抽出されている.

(2) 2 台のカメラの相対的な位置, 姿勢は固定されている.

(3) 2 台のカメラの画像平面上で障害物の像に同時に干涉しな い点として，始点，および終点が与えられる。

\section{2 エピポーラ拘束 [11]}

複数のカメラ間の相対的位置, 姿勢が固定されているときに は，その画像間にはエピポーラ拘束と呼ばれる幾何学的拘束が 存在する [11]. $\boldsymbol{p}_{1}=\left[\begin{array}{lll}x_{1} & y_{1} & 1\end{array}\right]^{T}, \boldsymbol{p}_{2}=\left[\begin{array}{lll}x_{2} & y_{2} & 1\end{array}\right]^{T}$ をそれぞれ， カメラ 1 , カメラ 2 における特徴点の同次べクトルとすると, エピポーラ拘束は

$$
\boldsymbol{p}_{1}{ }^{T} \boldsymbol{E} \boldsymbol{p}_{2}=0
$$

と与えられる.ここで, 行列 $\boldsymbol{E} \in \Re^{3 \times 3}$ は, 2 台のカメラの相 対的位置, 姿勢, およびカメラパラメータの関数であり, 相対 的位置, 姿勢が変化しない場合, 定数行列となる。この拘束は

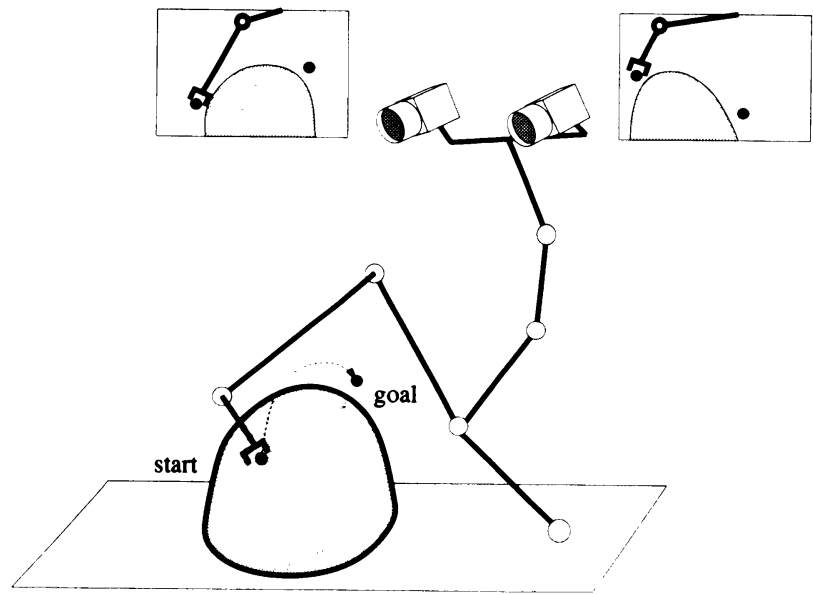

Fig. 1 Obstacle avoidance using visual servoing
一方の画像平面上でのある点は, 他方の画像平面上ではある直 線（エピポーラ線）上に対応する像があることを表している.

2 台のカメラ間で対応のついた最低 8 点が与えられれば, 行 列 $\boldsymbol{E}$ を同定することができる．ロボットがマニピュレータを 持つ場合, その先端が画像内で教示されれば, マニピュレータ を動作させることにより，このような点を観測することは容易 である。

\section{3 画像平面内の障害物回避への燸着}

従来の方法を用いて視覚サーボ系に障害物回避作業を実現さ せるには, カメラ間の障害物の像の対応から三次元の形状を再 構成し，これに基づいて作業座標系で目標軌道を計画し，これ を画像平面に投影して視覚サーボ系に対する目標值を生成する 方法が一般的であると考えられる。このような方法をとるには， ロボットや環境に対する詳しい知識を必要とし，それゆえモデ ル化誤差や外乱に対するロバスト性に欠ける.

画像平面上のセンサ情報を直接フィードバックする視覚サー ボ系においては, 環境の三次元再構成をしないために, センサ によりとらえられる画像特徴量を目標值に収束させるという サーボ系の動作によって，与えられた作業を遂行しなければな らない。そのためには三次元空間内の障害物回避問題を画像平 面内の障害物回避問題に帰着しなければならない.「2 台のカメ ラの画像上で，障害物の像に同時に干涉していない軌道は，実 際の空間においても障害物と干涉していない」という十分条件 を用いると，三次元の障害物回避は，画像平面内でエピポーラ 拘束を考慮した障害物回避であると考えられる (Fig. 2)．二次 元平面内の障害物回避については, 従来提案されている様々な アルゴリズム（文献 [12][13]など）を適用できると考えられる．

提案する㷌着法は, 障害物が何らかの形で背景から抽出され

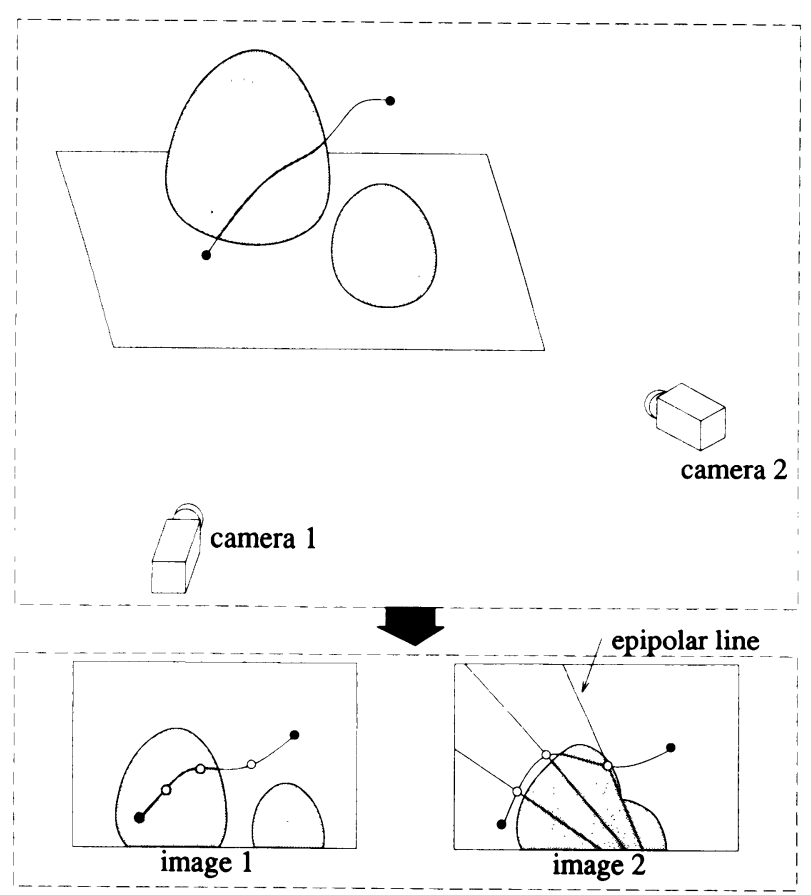

Fig. 2 3D obstacle avoidance is converted into constraint 2D avoidance 
ており，エピポーラ拘束行列 $\boldsymbol{E}$ が同定されていれば適用可能 である．障害物は，例えば背景から二值化などの単純な画像処 理で抽出できれば良く, カメラ間の画像の対応を必要としない ので, カメラの内部（焦点距離, 像中心, アスペクト比など), および外部（2台のカメラ間の相対的位置, 姿勢）パラメー夕 をあらかじめ校正する必要がない．また 2 台のカメラの画像間 で, 領域などの特徴に対応がついている必要はないことに注意 されたい。このため, 例えば筆者らが提案している適応機構を 持つ視覚サーボ系 [14]などとの併用により，環境に対する詳し い知識をほとんど使わないで障害物回避作業を遂行できる。

\section{4 障害物回避軌道の生成}

エピポーラ拘束を考虑に入れた，二次元平面内での障害物回 避に対しては，例えば，従来提案されている二次元平面内の移 動ロボットの障害物回避アルゴリズムなどを応用することによ り容易に導くことができる。ここでは，軌道生成法の一例とし て, 簡単な手法を示す (Fig. 3).

（1）仮定（1）より，障害物の領域は何らかの画像処理法によっ て背景より抽出されている。

（2）画像 1 での目標軌道を，始点と終点を結んだ直線とする． この直線を十分に細かい間隔で分割する。

(3) 同定されているエピポーラ拘束を用いて, 分割されたそれ ぞれの区分点に対応するエピポーラ線を画像 2 上で求める.

image of camera 1
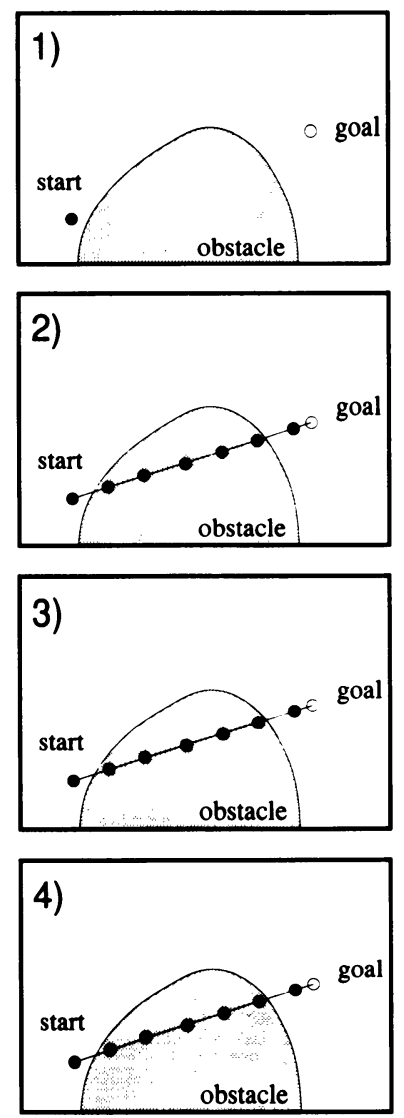

Fig. 3 Trajectory generation algorithm to avoid obstacles
（4）エピポーラ線上を走査し，障害物と干渉しない点を画像 2 上での目標軌道とする

\section{3. 障害物回避タスクの実現実験}

本章では，提案する手法と，2.4 節で示した簡単な軌道生成 アルゴリズムを用いて障害物回避軌道が生成されることを実験 的に示し，さらにこの軌道を適応機構を持つ視覚サーボ系 [14] に与えることによって，障害物回避作業が実現できることを実 験的に検証する。

\section{1 適応機粠を持つ視賞サーボ系}

本報告で実験に適用された適応機構を持つ視覚サーボ系と， 本報告で提案する障害物回避軌道生成法を組み合わせたシステ ムを Fig. 4 に示す.この視覚サーボ系は, 現在の画像特幑量 とこれらに対して与えられた目標軌道とからフィードバック/ フィードフォワード項を持つ制御入力を計算する部分と，ロボッ トの挙動を観測し、ロボットのパラメー夕を推定する推定器か らなる. パラメー夕推定器は, ロボットに対する入力と, 出力 としての画像特徵量を観測し, 最小二乗推定に類似した手法を 用いることによってパラメータを推定するものである．また， 視覚サーボの制御部は画像特徵量を目標值に収束させるための フィードバック項だけでなく，あらかじめ計算された目標值の 時系列をよりよく追従するためのフィードフォワード項を持つ ている。この視覚サーボ系は

・ロボット，環境に対する先験的な知識を必要としない，

・適用できるロボットについて, カメラの台数などの構造的 な制約がない,

・パラメータ推定器はロボットの真のパラメータを推定する のではなく，目標值追従に必要なパラメー夕を推定する，

・フィードバック項のみの視覚サーボ系に比べてょり性能の よい軌道制御が実現可能である。

などの特徵を持つ.

\section{2 実験システムの檴成}

Fig.5 に実験に用いたロボットの概観を示す。ロボットは 1 台のマニピュレータと, 地面に固定された 2 台のカメラから構 成される、マニピュレータとして，川崎重工製 6 自由度ロボッ トJs-5を，またカメラとして，エルモ社製カラー CCD カメラ UN401（焦点距離 $11[\mathrm{~mm}]$ ）を 2 台用いている. Fig. 6 に実験 システムの全容を示す.カメラで取り込まれた画像は DataCube 社製画像パイプラインプロセッサ MV200に送られる。 カメラ から取り込まれる画像サイズは $512 \times 480$ [pixel] であるが，こ れを水平方向に $1 / 2$ に縮小し， 1 枚あたり $256 \times 480$ [pixel]の

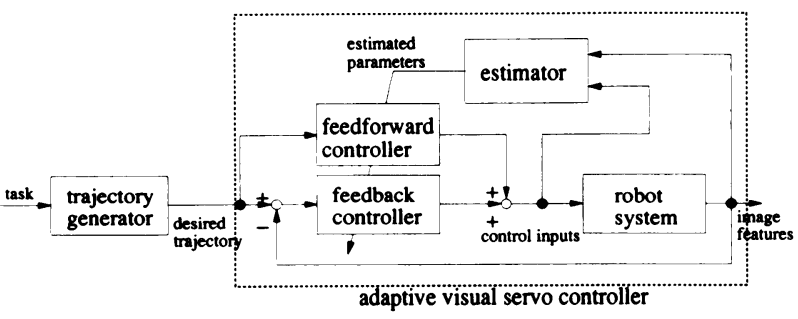

Fig.4 Proposed trajectory generator and adaptive visual servo controller 


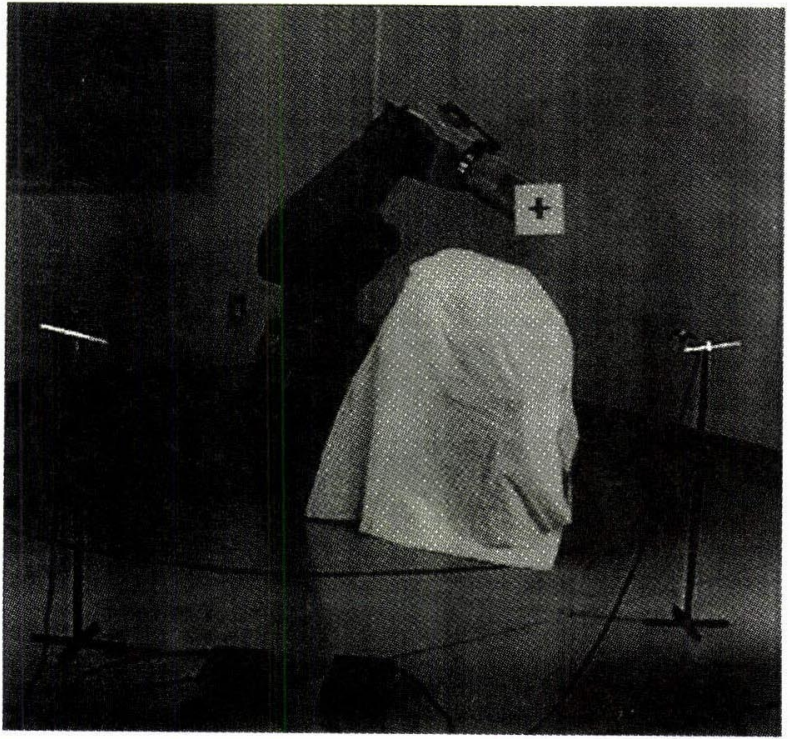

Fig. 5 Camera-manipulator system used for experiments

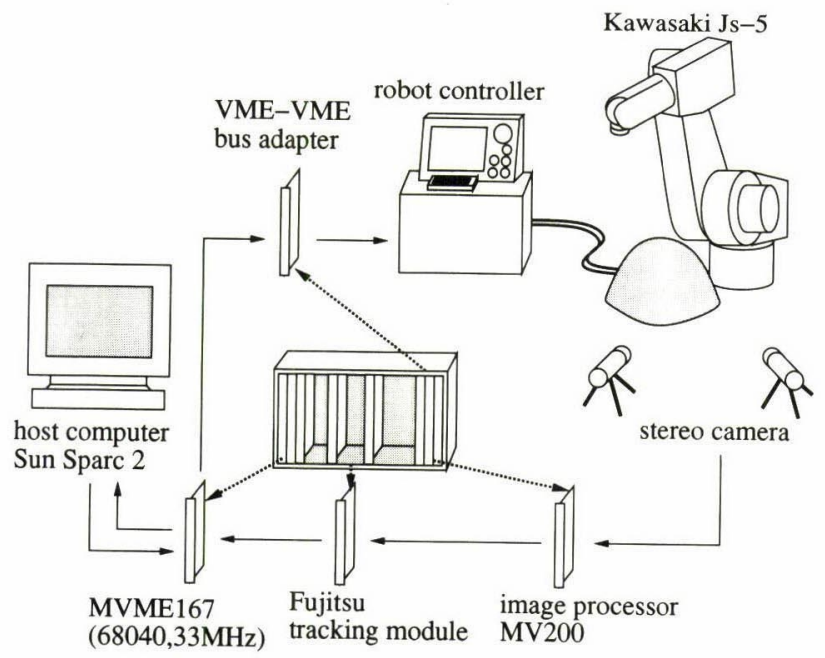

Fig.6 Experimental equipment

画像として，2枚の画像を一つの画像に合成したものをこのプロ セッサの出力としている。 またこの画像プロセッサでは, 障害物 を背景から抽出するための二值化操作も行われる。プロセッサ MV200 から出力された画像は, 富士通製トラッキングモジュー ルに送られる。このトラッキングモジュールは前もって与えら れた画像テンプレートと相関が最も高い画像が現在の画像平面 上のどこにあるかを検出できる [15]. トラッキングモジュール により得られた座標はホストコンピュータボード MVME167 (CPU: 68040, 33[MHz], motorola) に送られ, これをもとに 川崎重工製 6 自由度マニピュレータ Js -5 に対する出力が計算 される. 計算された出力は VME-VMEバスアダプタを通して, マニピュレータの専用コントローラに送られる。マニピュレー 夕は専用コントローラによって位置制御されている. 本実験で は姿勢は固定し, 手先位置 3 自由度をマニピュレータが持って いる自由度としている。この実験システムを用い, 適応機構を
Table 1 Feature points to estimate epipolar constraint

\begin{tabular}{|c|}
\hline$\left[x_{1}, y_{1}, x_{2}, y_{2}\right]$ \\
\hline$[170,168,185,162]$ \\
{$[126,134,157,142]$} \\
{$[96,100,128,122]$} \\
{$[95,111,96,141]$} \\
{$[96,126,68,160]$} \\
{$[41,181,46,220]$} \\
{$[68,277,33,297]$} \\
{$[106,389,273,391]$} \\
\hline
\end{tabular}

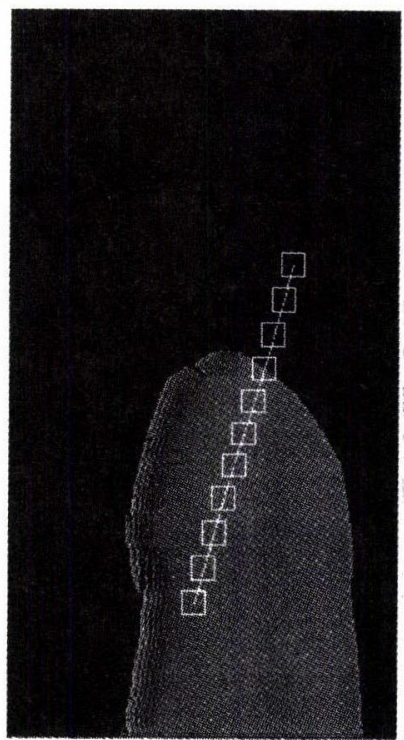

(a) frame 1

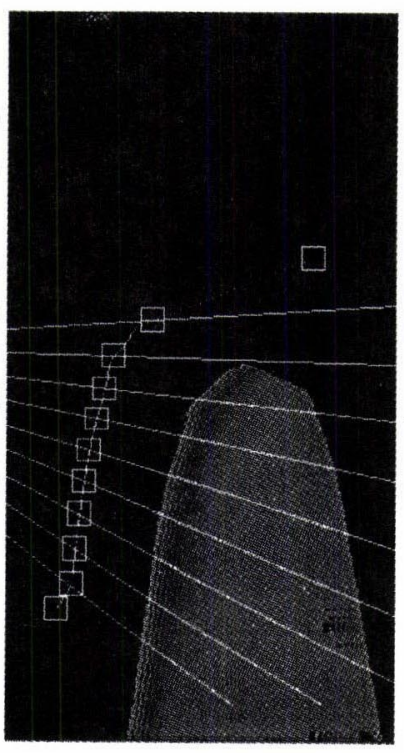

(b) frame 2
Fig. 7 Generated desired trajectories on the image planes

持つ視覚サーボプログラムを VxWorks 上の C 言語で記述した ところ，サンプリング時間は $33[\mathrm{~ms}]$ となった .

\section{3 実験結果}

\subsection{1 エピポーラ拘束の推定結果}

画像上でマニピュレータの手先を教示し, マニピュレータを 適当に動かすことによって，2枚の画像上で対応する 8 点を観 測し, これらの座標を用いて, エピポーラ拘束行列 $\boldsymbol{E}$ を推定し た。実験により得られた 8 点の画像特徴量べクトルを Table 1 に示す。これらの值より推定されたエピポーラ拘束行列 $\boldsymbol{E}$ は,

$$
\boldsymbol{E}=\left[\begin{array}{ccc}
-5.2 \times 10^{-5} & 1.0 \times 10^{-5} & -1.1 \times 10^{-2} \\
1.2 \times 10^{-4} & 2.5 \times 10^{-5} & 4.1 \times 10^{-2} \\
5.8 \times 10^{-3} & -3.3 \times 10^{-2} & 1.0
\end{array}\right]
$$

となる。

\subsection{2 障害物回避のための軌道生成}

本実験では，障害物の領域は白黒濃淡画像に対する二值化操 作により背景より抽出された。得られた障害物領域に対し，提 案する手法を用いて, Fig.7 に示すような障害物回避軌道を生 成することができた。マニピュレータには, 図中の軌道に沿っ て $33[\mathrm{~s}]$ で障害物回避をする時間軌道を与えた。 


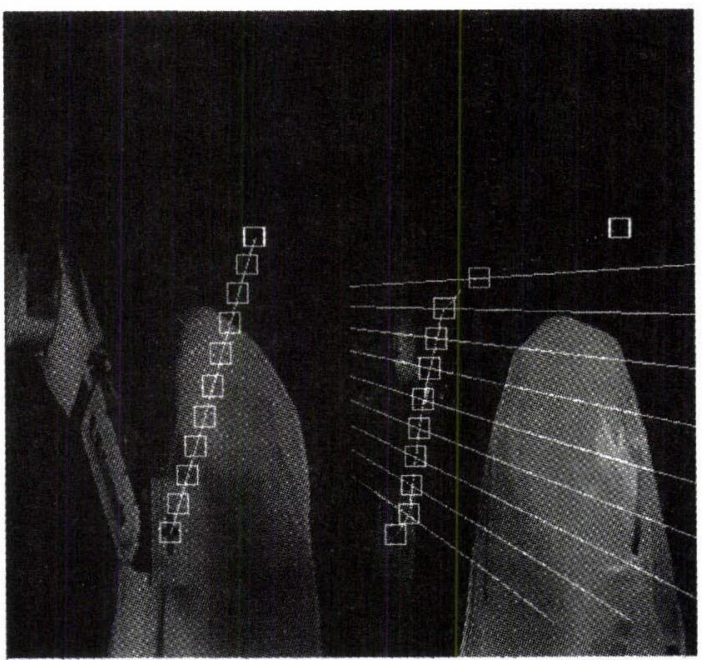

Fig. 8 Start posture of the manipulator

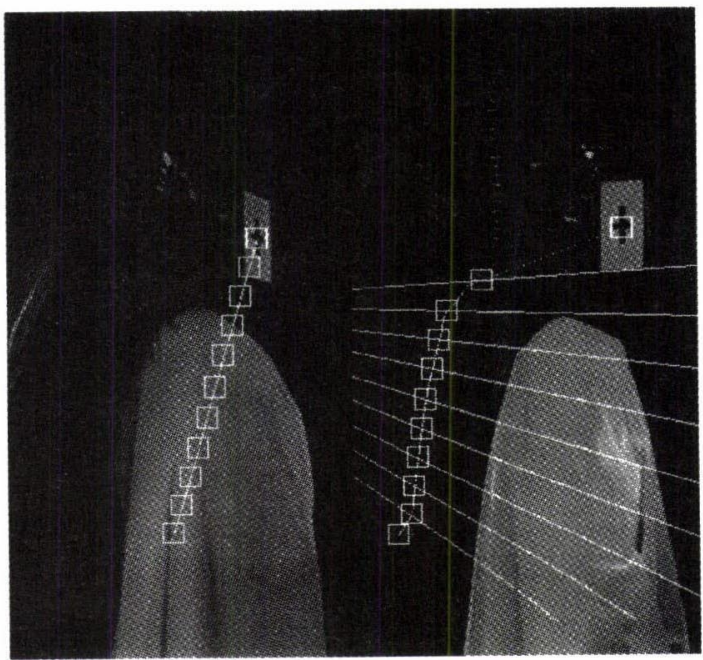

Fig.9 Goal posture of the manipulator

\section{3 .3 適応機構を持つ視覚サーボ系を適用した実験結果}

生成された障害物回避軌道を適応機構を持つ視覚サーボ系に 与えることによって, 障害物回避を実現する。障害物回避作業 を実現する前の状態と, 実現後の状態を Fig. 8, Fig.9 に示す. 視覚サーボ系によって制御されている間, マニピュレータの先 端が障害物と干涉しないことを実験により確認した。

Fig.10, Fig.11に, 画像平面上で視覚サーボ系に与えられ た目標軌道と，実際にマニピュレータの手先が動いた軌道との 誤差ノルムを示す. 制御の初期では, 視覚サーボ系はロボット のパラメータを十分に推定できないため, 与えられた軌道に追 従できないが, 10 秒経過後あたりより軌道に追従していること が分かる。

本実験では, 目標軌道を画像平面 1 上で等速になるように与 えている，本論文で提案している軌道計画法は，環境に対する 知識を持たないため, この結果生成される三次元空間内で実現 される速度については，これを予想することはできない。この 様な理由で, $t=33.0[\mathrm{~s}]$ で, 追従誤差が大きくなっているもの

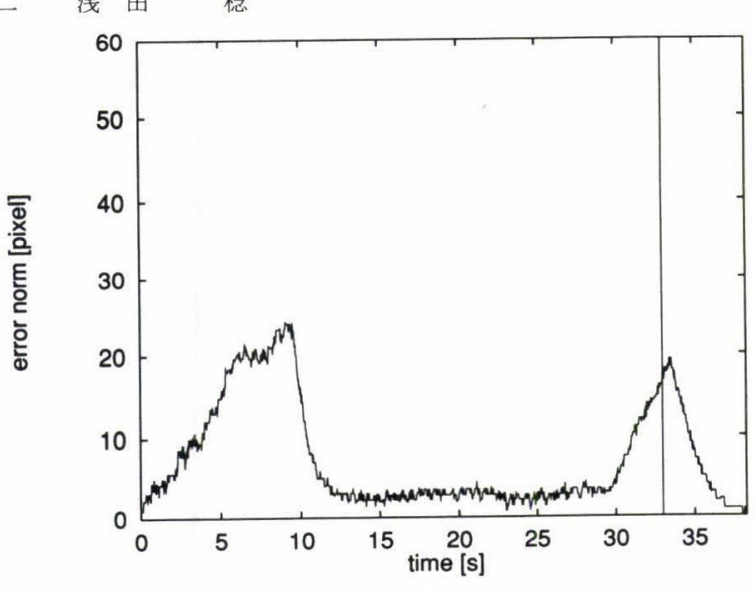

Fig.10 Error norm on image plane 1

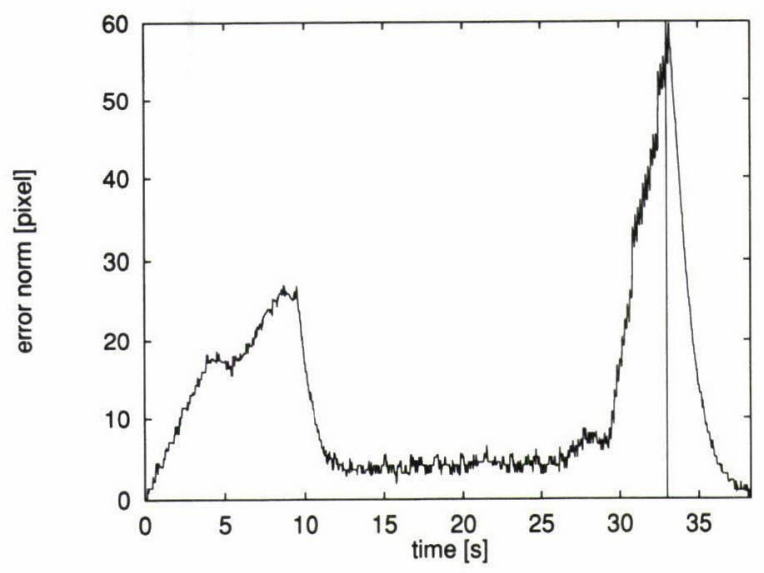

Fig. 11 Error norm on image plane 2

\section{と考えられる.}

これらの実験結果より, 提案する障害物回避軌道生成器と適 応機構を持つ視覚サーボ系の組み合わせにより，環境に対する 知識をほとんど使わなくても, 障害物回避作業を実現できるこ とが分かった。

\section{4. おわりに}

本論文では，視覚サーボ系を用いて，環境の三次元情報を再 構成せずに, 三次元空間内の障害物回避を画像平面内の障害物 回避問題に帰着する手法について述べた。そして, 簡単な障害 物回避アルゴリズムを用いて, 障害物回避軌道が生成されるこ とを実験的に確認し, 適応機構を持つ視覚サーボ系にこの軌道 を与えることによって, 障害物回避作業が遂行されることを実 験により示した。提案した方法は画像上の障害物領域の認識, エピポーラ拘束のほかに, 環境に対する知識を必要としないた め, 適応機構を持つ視覚サーボ系との組み合わせにより, 環境 に対する事前知識をほとんど使わずに，与えられた障害物回避 作業を遂行できる。したがって，ロボットシステムと環境に対 するキャリブレーションをほとんど必要としない.

仮定（3）が満たされるためには, カメラ間の相対的距離が, 障害物に対してある程度なければならない。この仮定が成立し 
ない場合には，さらに障害物を細かい領域に分割するなどの手 法を考慮する必要がある [16].

本論文では、ロボットマニピュレータ先端の障害物回避のみ を取り扱っている．本手法をロボットマニピュレータ全体の障 害物回避に適用するためには，ロボットマニピュレータの腕部 にいくつか画像特徵量を設定し, それらすべてについて, 同様 の障害物回避をすればよいと考えられる。そのためには,さら にこれらの画像特徴量の間の拘束を考慮した障害物回避アルゴ リズムと, 視党サーボ系を考える必要があり,このような方法 が今後の課題であると考えられる.

本論文では, 障害物回避作業を視覚サーボ系の目標軌道を設 計することにより実現しているが, 他の種々の作業に関しても このような目標軌道設計により遂行可能なものがあると考えら れ,これらの方策の提案が望まれる.

\section{参 考 文 献}

[1] Y. Aloimonos: "Introduction: Active Vision Revisited," Active Perception, Lawrence Erlbaum Associates, Publishers, 1993.

[2] P.I. Corke: "Visual Control of Robot Manipulators-A Review," Visual Servoing, pp.1-31, World Scientific, 1993.

[3] 橋本：“視覚フィードバック制御一静から動へ”、システム/制御/情 報, vol.38, no.12, pp.659-665, 1994.

[4] P. Allen, A. Timcenko, B. Yoshimi and P. Michelman: "Automated Tracking and Grasping of a Moving Object with a Robotic Hand-Eye System," IEEE Trans. on Robotics and Automation, vol.RA-9, no.2, pp.152-165, 1993.

[5] L.E. Weiss, A.C. Sanderson and C.P. Neuman: "Dynamic SensorBased Control of Robots with Visual Feedback," IEEE J. of Robotics and Automation, vol.RA-3, no.5, pp.404-417, 1987.
[6] B. Nelson, N.P. Papanikolopoulos and P.K. Khosla: "Visual Servoing for Robotic Assembly," Visual Servoing, pp.139-164, World Scientific, 1993.

[7] 加瀬, 丸, 西川, 宮崎: “ステレオ視によるマニピュレータのビジュ アルサーボ”, システム制御情報学会論文誌, vol.6, no.8, pp.360-367, 1993.

[8] 橋本, 木村：“ビジュアルサーボイング一非線形オブザーバアプロー チ—”, 日本ロボット学会誌, vol.13, no.7, pp.986-993, 1995.

[9] G.D. Hager: "Real-Time Feature Tracking and Projective Invariance as a Basis for Hand-Eye Coordination," In Proc. of IEEE Int. Conf. on Computer Vision and Pattern Recognition, pp.533539, 1994

[10] G.D. Hager, W.-C. Cang and A.S. Morse: "Robot Feedback Control Based on Stereo Vision: Towards Calibration-Free HandEye Coordination," In Proc. of IEEE Int. Conf. on Robotics and Automation, pp.2850-2856, 1994.

[11] H.C. Longuet-Higgins: "A computer Algorithm for Reconstructing a Scene from Two Projections," Nature, vol.293, pp.133-135, 1981.

[12] O. Khatib: "Real-Time Obstacle Avoidance for Manipulators and Mobile Robots," The Int. J. of Robotic Research, vol.5, no.1, pp.9098, 1986.

[13] H. Noborio: "A Path-Planning Algorithm for Generation of an Intuitively Reasonable Path in an Uncertain 2D Workspace," In Proc. of the 1990 JAPAN-USA Symposium on Flexible Automation, pp.477-480, 1992.

[14] 細田, 浅田：“構造やパラメー夕に関する先験的な知識を必要としな いフィードフォワード補償器を持つ適応型ビジュアルサーボ系の構 成”, 日本ロボット学会誌, vol.14, no.2, pp.313-319, 1996.

[15] 稲葉：“局所相関プロセッサを用いたロボットビジョン”, 日本ロボッ 卜学会誌, vol.13, no.3, pp.327-330, 1995.

[16] 細田, 浅田：“複数画像情報を用いた障害物回避行動の実現”, 第 13 回日本ロボット学会学術講演会予稿集, pp.625-626, 1995.

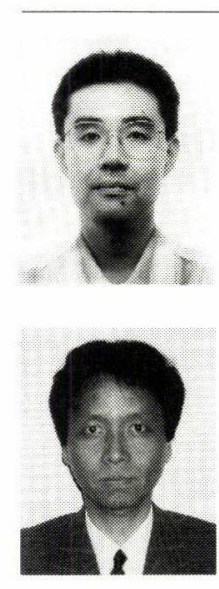

細田 耕 (Koh Hosoda)

1965 年 11 月 9 日生. 1993 年京都大学大学院工学 研究科機械工学専攻博士後期課程修了. 同年大阪 大学工学部助手となり, 現在に至る。1995 年日本 ロボット学会研究奨励賞受賞. 視覚サーボ系, 知能 ロボットの研究に従事. 博士 (工学). IEEE, 計測 自動制御学会の会員. (日本ロボット学会正会員)

\section{浅田 稔 (Minoru Asada)}

1953 年 10 月 1 日生. 1982 年大阪大学大学院基礎工 学研究科博士後期課程修了. 同年同大学基礎工学 部助手. 1989 年同大学工学部助教授, 1995 年同教 授となり現在に至る。この間， 1986 年から 1 年間 米国メリーランド大学客員研究員. 1989 年情報処 理学会研究賞, 1992 年 IEEE/RSJ IROS'92 Best Paper Award 受賞. 知能ロボットの研究に従事. 工学博士. 電子情 報通信学会, 情報処理学会, 人工知能学会, 日本機械学会, 計測自動 制御学会, システム制御情報学会, IEEEなどの会員.

(日本ロボット学会正会員)

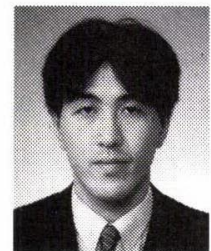

阪本健二 (Kenji Sakamoto)

1969 年 7 月 14 日生. 1995 年大阪大学大学院工学研 究科電子制御機械工学専攻博士前期課程修了. 同 年松下電工株式会社に入社, 現在に至る。在学中 視覚サーボ系を用いたロボットの制御の研究に従 事.

(日本ロボット学会正会員) 